\title{
ANALISIS FAKTOR-FAKTOR YANG BERPENGARUH TERHADAP PENGGUNAAN LEMBAGA BANK SYARIAH: STUDI DI PROPINSI DAERAH ISTIMEWA YOGYAKARTA
}

\author{
Duddy Roesmara Donna \\ Minat Studi Ekonomi Islam \\ Program Studi Agama dan Lintas Budaya Sekolah Pascasarjana Universitas Gajah Mada \\ Email: duddyroes@yahoo.com
}

\begin{abstract}
This research aims to analyze factors that affect the using of sharia finance institution in the Province of DIY. This research involved 150 respondents distributed throughout Yogyakarta City, Bantul Regency, Kulon Progo, Gunungkidul Regency, and Sleman Regency. A purposive non-probability sampling method was used to predict population behavior, with factor analysis as a tool of analysis. The preference of using sharia finance institution was affected by institution factor, including institutional ones, loyalty of Islamic law, service, and the suitability of product.
\end{abstract}

Keywords: preference, sharia finance institution, factor analysis.

\begin{abstract}
ABSTRAK
Penelitian ini bertujuan untuk menganalisis faktor-faktor yang berpengaruh terhadap penggunaan lembaga keuangan syariah di Provinsi DIY. Penelitian dilakukan dengan 150 responden yang terbagi di setiap wilayah, yaitu Kota Yogyakarta, Kabupaten Bantul, Kabupaten Kulon Progo, Kabupaten Gunungkidul, dan Kabupaten Sleman. Metode sampel non probabilitas dengan sampel purposif digunakan untuk memprediksi perilaku populasi dengan analisis faktor sebagai alat analisisnya. Preferensi masyarakat Provinsi DIY terhadap lembaga keuangan syariah dipengaruhi oleh faktor kelembagaan, faktor ketaatan terhadap syariah Islam, faktor pelayanan, dan faktor kesesuaian produk.
\end{abstract}

Kata Kunci: preferensi, lembaga keuangan syariah, analisis faktor 


\section{PENGANTAR}

Fungsi intermediasi adalah salah satu fungsi yang penting dalam perekonomian. Lembaga keuangan syariah merupakan salah satu lembaga yang berperan penting pada proses intermediasi tersebut. Masih banyak permasalahan yang muncul pada penerapan lembaga keuangan syariah. Seringkali masyarakat masih menganggap bahwa tidak ada bedanya meminjam di lembaga keuangan syariah dengan di lembaga keuangan konvensional. Beberapa mereka melihat bahwa meminjam di lembaga keuangan syariah lebih mahal dan lebih berbelit-belit prosedurnya dibandingkan lembaga keuangan konvensional. Beberapa bahkan lembaga keuangan syariah hanya merupakan bentuk "kelatahan" akan kondisi perekonomian, dan tak ada bedanya dengan kapitalisme syariah.

Meskipun terdapat perubahan ke arah yang lebih baik (ada kecenderungan lembaga keuangan syariah untuk meningkatkan pangsa pembiayaan dengan prinsip bagi hasil), tetapi ketimpangan antara pembiayaan dengan prinsip bagi hasil dan jual beli sewa masih relatif besar. Total pembiayaan dengan prinsip bagi hasil tidak pernah lebih dari setengah total pembiayaan dengan prinsip jual beli. Hal tersebut merupakan sebuah fenomna yang menarik karena diharapkan pembiayaan dengan prinsip bagi hasil lebih mendominasi (Donna, 2006).

Pembiayaan dengan prinsip bagi hasil diharapkan lebih menggerakkan sektor riil karenamenutupkemungkinandisalurkannya dana pada kepentingan konsumtif dan hanya pada usaha produktif. Bila ditinjau dari konsep bagi hasil, maka harus ada return yang dibagi, hal tersebut hanya bisa terjadi bila uang digunakan untuk usaha produktif. Bila ditinjau dari prinsip ketaatan terhadap syariah, pembiayaan dengan prinsip jual beli dan sewa menimbulkan celah lebih besar untuk melakukan penyimpangan terhadap prinsip syariah (Donna, 2006).

Menurut Wijaya (2006), alasan utama nasabah yang hanya memiliki rekening di lembaga bank syariah adalah kekhasan aspek syariah (penerapan prinsip syariah, keseseuai dengan ajaran Islam, dan tidak ada riba). Nasabah tetap mempertahankan rekening di bank konvensional karena aksesibilitas dan fasilitas bank konvensional lebih bagus dibanding bank syariah serta kebijakan kantor / bisnis yang berhubungan dengan bank konvensional. Sedangkan alasan paling dominan bagi nasabah bank konvensional tidak berminat terhadap produk bank syariah disebabkan oleh informasi tentang lembaga keuangan syariah masih kurang memadai. Preferensi dan sumber informasi nasabah tentang bank syariah juga dianalisis dalam penelitian ini. Aspek yang akan dianalisis lebih lanjut adalah sumber informasi bank syariah, lokasi ideal bank syariah, busana yang dikenakan bagi karyawan pria dan wanita, serta bahasa yang digunakan dalam penamaan produk lembaga keuangan syariah. Hasil analisis ini akan digunakan sebagai bahan pendukung dalam penyusunan strategi pemasaran yang akan direkomendasikan untuk bank syariah. Keberadaan dan tampilan kantor merupakan sumber informasi utama bagi nasabah bank di wilayah Propinsi DIY untuk mendapatkan informasi tentang lembaga keuangan syariah. Lokasi yang dianggap ideal bagi nasabah untuk mendirikan kantor adalah di daerah bisnis (toko/pasar). Karyawan Wanita bank syariah sebaiknya menggunakan jilbab, sedangkan karyawan pria tidak harus menggunakan pakaian koko dan peci. Produk bank syariah sebaiknya menggunakan bahasa Indonesia dalam penamaan produknya.

Hasil riset tersebut menunjukkan bahwa ada masalah di dalam industri lembaga keuangan syariah. Produk yang ada dalam lembaga keuangan syariah masih kearab-araban, bagi beberapa orang hal ini merupakan masalah karena kendala pemahaman bahasa. Masalah lain adalah nasabah lembaga keuangan syariah sama dengan nasabah bank konvensional. Hasilnya adalah banyaknya floating costumer yang ada di lembaga keuangan syariah. Hal ini tak lepas dari kemiripan produk dan 
sistem lembaga keuangan syariah dengan bank konvensional. Lembaga keuangan syariah masih belum bisa menggeser jual beli (murabahah) sebagai produk unggulan mereka dengan bagi-hasil (mudharabah) yang lebih berjiwa ekonomi syariah.

Bank syariah merupakan salah satu bentuk lembaga keuangan syariah. Penelitian ini memperluas cakupan karena banyak macam lembaga keuangan syariah selain bank yang mungkin cocok bagi sekelompok masyarakat.

Terdapat keunikan dan perbedaan dalam pemanfaatan dana pada lembaga keuangan syariah dan konvensional. Dalam lembaga keuangan konvesional pemanfaatan dilakukan dengan cara meminjamkan uang dengan jangka waktu tertentu dengan tingkat keuntungan (suku bunga) yang ditetapkan di awal perjanjian. Dalam lembaga keuangan syariah terdapat dua macam prinsip pembiayaan yang sering digunakan, yaitu prinsip bagi hasil dan prinsip jual beli sewa.

Prinsip bagi hasil dalam lembaga keuangan syariah mengharuskan peminjam menggunakan dana untuk usaha produktif dan tidak memungkinkan untuk penggunaan konsumtif karena harus ada pendapatan usaha yang dibagikan ke pihak bank. Prinsip bagi hasil terdiri dari pembiayaan mudharabah dan musyarakah. Prinsip jual beli dan sewa membuka kemungkinan untuk penggunaan dana tujuan konsumtif meskipun tidak tertutup kemungkinan untuk usaha produktif. Prinsip jual beli dan sewa terkesan lebih diminati oleh lembaga keuangan syariah karena relatif lebih aman (keuntungan ditentukan di depan) dan tidak memerlukan pengawasan yang ketat seperti prinsip bagi hasil. Berdasarkan fakta yang ada, diduga terdapat karakteristik yang berbeda pada kedua model pembiayaan di atas. Dengan konsep dan karakteristik yang berbeda maka diduga faktor-faktor yang mempengaruhi permintaan kedua macam pembiayaan tersebut juga berbeda sehingga diperlukan langkah yang berbeda pula untuk membuat kebijakan terhadap kedua jenis pembiayaan tersebut.
Permasalahan dalam penelitian ini adalah faktor apa sajakah yang mempengaruhi permintaan pembiayaan dengan bagi hasil (uncertainty contract) dan jual beli/sewa (certainty contract).

Penelitian ini bertujuan untuk mengidentifikasi faktor-faktor yang mempengaruhipemilihanmodel pembiayaan pada lembaga keuangan syariah.

Schaik berpendapat bahwa salah satu dari prinsip Ekonomi Islam yang melandasi bank syariah adalah larangan riba (Schaik, 2001). Untuk menghindari riba sistem bagi hasil dan risiko merupakan solusi yang disarankan. Prinsip utama dalam bank syariah adalah keuangan yang didasarkan perdagangan dan berbagi risiko dengan mitranya.

Dalam penelitian Nasution (2006), yang berjudul "Analisis Potensi dan Preferensi Masyarakat terhadap Bank Syariah di Wilayah Kota Medan", diteliti mengenai preferensi masyarakata Kota Medan terhadap bank Syariah dengan menggunakan metode pearson product moment. Preferensi yang digunakan dalam penelitian tersebut, yaitu (1) keuntungan relatif, (2) keterbukaan informasi, (3) kompabilitas, (4) kompleksitas, dan (5) triabilitas.

Lembaga Penelitian Instititut Pertanian Bogor (2004)menyatakan bahwa faktor-faktor yang mempengaruhi masyarakat dalam menggunakan bank syariah di Jawa Barat dapat ditelaah dengan menggunakan model logit. Faktor-faktor yang mempengaruhi masyarakat dalam mengguakan produk maupunjasa bank syariah, yaitu (1) pekerjaan utama, pengusaha vs non-pengusaha, (2) penghasilan, rendah vs non-rendah, (3) aksesibilitas, (4) keterbukaan terhadap informasi, (5) penerimaan terhadap bank konvensional, (6) pertimbangan memilih bank karena lokasi/akses, (7) pertimbangan memilih bank karena pelayanan, (8) pertimbangan memilih bank karena kredibilitas, (9) pertimbangan memilih bank karena fasilitas, (10) pertimbangan memilih bank karena statusnya, (11) pengguna jasa bank konvensional - pinjaman, (12) 
pengguna jasa bank konvensional - layanan jasa, (13) tingkat pengetahuan terhadap bank syariah.

Pusat Pengkajian Bisnis dan Ekonomi Islam Fakultas Ekonomi Universtias Brawijaya (2000) menyebutkan bahwa variabel-variabel penting dalam meneliti preferensi masyarakat Jawa Timur adalah (1) perilaku masyarakat, (2) karakteristik masyarakat, (3) stimuli pasar, dan (4) stimuli lainnya. Metode penelitian yang dipakai adalah dengan estimasi model logit. Kesimpulan yang diperoleh dari penelitian tersebut menyatakan bahwa dari hasil estimasi logit masyarakat indivual, keputuasan untuk tidak memilih bank syariah dipengaruhi oleh tujuh faktor, yaitu: (1) payment period, (2) warranties, (3) location, (4) economic circumtances, (5) role and statues, (6) age and life stages, dan (7) family, serta (8) Pendidikan. Sedangkan hasil estimasi logit dari responden perusahaan mengindikasikan bahwa ada empat faktor yang mempengaruhi perusahaan untuk memilih bank syariah atau bank konvensional, yaitu (1) service, (2) size, (3) brand name, (4) reference group. Dari keempat faktor yang ada, faktor reference group yang memiliki posisi paling dominan.

Hasil penelitian Direktorat Perbankan Syariah - Bank Indonesia - dengan Institut Pertanian Bogor (2004), mengenai potensi, preferensi dan perilaku masyarakat terhadap bank syariah di Wilayah Kalimantan Selatan menyatakan bahwa variabel-variabel yang mempengaruhi keputusan masyarakat untuk menggunakan produk atau jasa perbankan syariah di Kalimantan Selatan, yaitu (1) jenis pekerjaan, (2) pertimbangan profesionalisme dan aksesibilitas bank, (3) tingkat pengetahuan tentang bank syariah, (4) posisi tokoh keagamaan, (5) persepsi terhadap bunga yang bertentangan dengan agama, (6) kesan positif terhadap bank syariah, dan (7) keberadaan bank syariah. Sedangkan keputusan yang mempengaruhi masyarakat untuk terus menggunakan produk atau jasa perbankan syariah disebabkan oleh: (1) Variabel-variabel tingkat pendidikan, (2) pendidikan formal bisnis, (3) keterbukaan terhadap informasi, (4) pertimbangan kemapanan dan asesibilitas bank, (5) pengetahuan terhadap bank, dan (6) status nasabah bank syariah saja. Adapun variabelvariabel yang mempengaruhi masyarakat untuk ingin menggunakan produk atau jasa perbankan syariah sebagai berikut: (1) pendidikan non formal baik keagamaan maupun bisnis, (2) jenis pekerjaan pengusaha dan karyawan, (3) keterbukaan terhadap informasi, (4) pengetahuan terhadap bank syariah, (5) kesan terhadap bank syariah, (6) Persetujuan terhadap prinsip syariah dan (7) status responden (nasabah bank konvensional dan non-nasabah bank). Faktor-faktor yang menjadi pertimbangan masyarakat dalam memilih bank, baik bank konvensional maupun bank syariah, relatif sama. FaktorFaktor utama tersebut: (1) aksesibilitas, (2) kredibilitas, (3) profesionalisme pelayanan, dan (5) faslilitas pelayanan. Bunga/bagi hasil tidak menjadi faktor pertimabangan utama dalam hal ini.

Lembaga Penelitian Universitas Andalas bekerjasama dengan Bank Indonesia Padang (2001) melakukan penelitian tentang potensi, preferensi, dan perilaku masyarakat terhadap bank syariah di Sumatera Barat, dengan menggunakan model regresi logit (logistic regression model) menyebutkan bahwa faktor-faktor yang mempengaruhi persepsi dan preferensi masyarakat untuk memilih bank konvensional sebagai berikut: (1) variabel sosio-ekonomi, (2) variabel pelayanan, (3) variabel aksebilitas, dan (4) variabel keamanan. Adapun faktorfaktor yang mempengaruhi persepsi dan preferensi masyarakat untuk memilih Bank Syariah adalah (1) faktor sosio-ekonomi, (2) faktor pemahaman tentang bagi hasil, dan (3) faktor pemahaman terhadap bank syariah. Hasil penelitan di Sumatera Barat menemukan bahwa nasabah bank syariah umumnya berasal dari golongan masyarakat menengah-atas. Perbedaan ini disebabkan oleh perkembangan yang lebih baik di lembanga perbankan syariah di Jawa Barat, dibandingkan dengan di Sumatera Barat. Hal ini dikarenakan jumlah bank syariah 
yang masih terbatas, informasi mengenai sistem operasi bank syariah juga terbatas yang akan mengakibatkan ketidak-tahuan golongan menengah-atas terhadap prosedur pembiayaan dan pengembalian pada bank syariah, yang pada akhirnya akan mempengaruhi preferensi mereka terhadap bank syariah.

Data yang digunakan dalam kegiatan ini meliputi primer. Data primer digali dari preferensi masyarakat di Kota Yogyakarta, Kabupaten Bantul, Kabupaten Kulon Progo, Kabupaten Gunungkidul, dan Kabupaten Sleman terhadap pembiayaan syariah. Karakteristik data yang digunakan adalah data ordinal dengan skala likert (1 sampai 5).

Metode pemilihan sampel yang digunakan adalah non-probability dengan metode purposive sampling. Populasi dalam penelitian ini adalah masyarakat di Provinsi DIY yang pernah menggunakan layanan di lembaga keuangan syariah. Dikarenakan jumlah populasi sulit diidentifikasi, maka digunakan non probability sampling. Penggunaan non probability dengan purposive sampling merupakan metode sampling yang mendasarkan pada kriteria tertentu dalam penelitian. Kriteria yang digunakan adalah responden yang pernah menggunakan pelayanan lembaga keuangan syariah. Jumlah sample direncanakan sebesar 150 yang tersebar di tiap kota/kabupaten di Provinsi DIY.

Penelitian ini menggunakan metode kuantitatif dengan pendekatan analisis faktor. Analisis Faktor merupakan teknik untuk mengombinasikan pertanyaan atau variabel yang dapat menciptakan faktor baru serta mengombinasikansasaranuntukmenciptakan kelompok baru secara berturut-turut. Dibentuk dari teknik analysis of interdependence karena mereka menganalisa interdependence dari pertanyaan, variabel atau sasaran. Tujuannya adalah menghasilkan pemahaman yang mendasari struktur pertanyaan, variabel, sasaran dan mengkombinasikannya ke dalam variabel atau kelompok. Beberapa hal yang perlu diperhatikan dari analisis faktor sebagai berikut:
1. Tujuan: memiliki dua fungsi utama yaitu mengidentifikasi dasar konstruk (variabel yang terbentuk dari indikator yang telah dikelompokkan) dalam data dan penyederhanaan untuk mengurangi jumlah variabel suatu set yang dapat dikendalikan.

2. Metodologi: prosedur analisis faktor dalam penerapannya menggunakan principal component dan common factor analysis.

Principal component merupakan sasaran yang meringkas informasi dalam sejumlah variabel yang besar ke dalam beberapa faktor. Secara konseptual principal component didasarkan pada total informasi dalam setiap variabel. Secara normal principal component analysis merupakan tahap pertama dalam factor analysis dan akan digambarkan dari geometric perspective dalam konteks suatu sampel. Di dalam principal component analysis dibahas mengenai:

- Factor yaitu penyederhanaan variabel atau konstruk di mana secara tidak langsung diamati, tetapi kebutuhannya diduga dari input variabel.

- How many factor merupakan berapa banyak faktor yang terlibat dalam suatu model. Adanya jumlah yang pasti dari konstruk input variabel yang diukur. Konstruk didefinisikan sebelum analisis serta diperoleh dari teori dan pengetahuan mengenai situasi. Data merupakan faktor yang dianalisa sampai konstruk ini muncul sebagai faktor.

- Eigenvalue criteria mewakili sejumlah variance dalam variabel awal yang dikumpulkan dengan sebuah faktor dengan kriteria lebih dari 1,0.

- Screen plot criteria plot merupakan plot dari eigenvalues berlawanan dengan sejumlah faktor supaya adanya keturunan.

- Percentage of variance criteria merupakan penurunan yang ditentukan di mana persentase yang dikumulatifkan dari variance diturunkan oleh faktor tingkat kepuasan yang dicapai. 
- Significance test criteria untuk menentukan signifikansi statistik dari sebagian eigenvalue dan mempertahankan beberapa faktor yang merupakan statistik signifikan.

- Factor scores salah satu output dari program factor analysis yang merupakan nilai untuk setiap faktor bagi seluruh responden. Faktor diturunkan dalam variabel di mana factor score dihitung dari pengetahuan variabel yang dikumpulkan.

- Factor interpretation berdasarkan pada factor loading merupakan hubungan faktor ke variabel dan digunakan untuk membantu menginterpretasikan faktor.

- Communality merupakan persentase dari variance variabel yang mengkontribusi korelasi dengan variabel lainnya atau common untuk variabel lainnya.

- Variance explained merupakan ringkasan pengukuran yang mengindikasi berapa banyak total variance awal dari keseluruhan variabel faktor yang mewakilinya.

- Factor rotation menghasilkan beberapa solusi (loading dan factor score) untuk setiap data yang dibentuk dari factor rotation dan dihasilkan oleh factor rotation scheme.

Alasan membentuk factor analysis pada data adalah untuk memperoleh pandangan dari kelompok variabel yang muncul dan dapat dilakukan dengan memilih satu, dua atau lebih input variabel untuk mewakili setiap faktor dan menganti input variabel awal dengan factor score. Factor analysis sebagai berikut:

- Application: factor analysis digunakan untuk mengidentifikasikan dasar dimensi atau konstruk dalam data dan mengurangi sejumlah variabel dengan mengeliminasi kelebihannya.

- Input: menggunakan sekumpulan nilai variabel untuk setiap individu dan sasaran dalam suatu sampel.

- Output yang dihasilkan adalah factor loading, factor score, dan persentase variance yang dijelaskan.
- Key assumption biasanya terdapat faktor yang mendasari variabel dan variabel secara lengkap dan cukup mewakili faktor ini.

- Limitations of factor analysis dimana factor analysis merupakan proses subjektivitas yang tinggi.

Common factor analysis hanya berpusat pada variance (pengukuran jumlah informasi yang disampaikan oleh setiap faktor) yang dibagikan diantara keseluruhan variabel dan dapat diringkas sebagai metode transforming the original variabel into new, noncorrelated variabel yang disebut faktor. Common factor analysis merupakan usaha peneliti untuk menemukan dasar dimensi di sekitar variabel awalnya.

Secara garis besar, tahapan pada analisis faktor sebagai berikut:

1. Memilih variabel yang layak dimasukkan dalam analisis faktor. Oleh karena analisis faktor berupaya mengelompokkan sejumlah variabel, maka seharusnya ada korelasi yang cukup kuat diantara variabel, sehingga akan terjadi pengelompokkan. Jika sebuah variabel atau lebih berkorelasi lemah dengan variabel lainnya, maka variabel tersebut akan dikeluarkan dari analisis faktor. Alat seperti MSA atau Barlett's Test dapat digunakan untuk keperluan ini.

2. Setelah sejumlah variabel terpilih, maka dilakukan ektraksi variabel tersebut hingga menjadi satu atau beberapa faktor. Beberapa metode pencarian faktor yang sering digunakan adalah Principal Component dan Maximum Likehood.

3. Faktor yang terbentuk pada banyak kasus, kurang menggambarkan perbedaan diantara faktor-faktor yang ada. Hal tersebut dapat mengganggu analisis karena justru sebuah faktor harus berbeda secara nyata dengan faktor lain. Untuk itu, jika isi faktor masih diragukan, maka dapat dilakukan proses rotasi untuk memperjelas apakah 
faktor yang terbentuk sudah secara signifikan berbeda dengan faktor lain.

Setelah faktor benar-benar sudah terbentuk, maka proses dilanjutkan dengan menamakan faktor yang ada dan dilakukan langkah validasi hasil faktor (Santosa dan Tjiptono, 2001).

\section{PEMBAHASAN}

Untuk menganalisis faktor-faktor yang mempengaruhi pemilihan lembaga keuangan syariah dan model pembiayaan di lembaga keuangan syariah digunakan analisis faktor. Secara garis besar, proses analisis faktor ditempuh dengan dua langkah yaitu ekstraksi dan rotasi.

\section{Proses Ekstraksi}

Langkah pertama adalah melihat nilai $\mathrm{KMO}$ and Bartlett's Ttest. Angka K-M-O Measure of Sampling Adequacy (MSA) adalah 0,741 . Oleh karena angka MSA diatas 0,5 maka kumpulan variabel tersebut dapat diproses lebih lanjut. Kesimpulan yang sama dapat dilihat pula pada angka Bartlett's Test (yang ditampakkan pada angka Chi Square) sebesar 1,260 dengan signifikansi 0,000. Selanjutnya tiap variabel dianalisis untuk mengetahui mana yang dapat diproses lebih lanjut dan mana yang harus dikeluarkan.

Pada tabel 1 (Anti Image Correlation) yang menandakan besaran MSA sebuah variabel. Adapun pedoman yang digunakan adalah, kalau nilai MSA lebih besar dari 0,5 maka variabel tersebut tetap dipakai dalam analisis selanjutnya. Kalau nilai MSA lebih kecil dari 0,5, maka variabel tersebut dikeluarkan dari analisis. Dapat dilihat bahwa ke-16 indikator mempunyai nilai MSA yang lebih dari 0,5 sehingga kesemua indikator dipakai dalam proses selanjutnya.

Tabel 1. Nilai MSA dari Anti Image Correlation dan Communalities

\begin{tabular}{ccc}
\hline Indikator & $\begin{array}{c}\text { Anti Image } \\
\text { Correlation }\end{array}$ & Communalities \\
\hline i1 & 0,595 & 0,770 \\
i2 & 0,530 & 0,760
\end{tabular}

\begin{tabular}{ccc}
\hline Indikator & $\begin{array}{c}\text { Anti Image } \\
\text { Correlation }\end{array}$ & Communalities \\
\hline i3 & 0,874 & 0,588 \\
i4 & 0,771 & 0,760 \\
i5 & 0,776 & 0,686 \\
i6 & 0,738 & 0,660 \\
i7 & 0,825 & 0,723 \\
i8 & 0,788 & 0,631 \\
i9 & 0,831 & 0,807 \\
\hline i10 & 0,729 & 0,868 \\
i11 & 0,747 & 0,872 \\
i12 & 0,758 & 0,578 \\
i13 & 0,876 & 0,719 \\
\hline i14 & 0,556 & 0,902 \\
\hline i15 & 0,584 & 0,866 \\
\hline i16 & 0,848 & 0,596 \\
\hline
\end{tabular}

Sumber: Data Primer, diolah

\section{Proses Rotasi}

Seluruh proses rotasi dalam penelitian ini menggunakan principal component analysis dengan metode rotasi varimax. Penggunaan metode tersebut disebabkan karakteristik analisis faktor yang bersifat eksploratori (bukan konfirmatori). Analisis eksploratori lebih sesuai untuk menganalisis sesuatu yang belum baku landasan terorinya atau belum banyak penelitian sebelumnya yang serupa. Tabel 1 menunjukkan bahwa semua indikator mempunyai nilai communalities di atas 0,5 sehingga semua indikator digunakan dalam proses selanjutnya. Nilai communalities sebesar 0,596 dari I16 menunjukkan bahwa sekitar 59,6 persen dari Indikator16 dapat dijelaskan oleh faktor yang terbentuk nanti. Demikian juga dengan variabel lain.

Langkah selanjutnya adalah proses rotasi. Tabel 2 menunjukkan angkaangka sebagai hasil dari proses rotasi memperlihatkan distribusi yang lebih jelas dan nyata dibandingkan dengan jika tidak dilakukan rotasi. Dari hasil Tabel 2 terlihat ada sebuah indikator yang mempunyai korelasi ganda, yaitu I9 (sembilan belas). Ada indikator yang memiliki nilai korelasi ganda, maka dilakukan proses analisis faktor ulang dengan menghilangkan variabel yang 
memiliki korelasi ganda tersebut. Dengan menghilangkan variabel yang memiliki nilai korelasi ganda tersebut diharapkan nantinya akan terbentuk faktor yang lebih baik dan memiliki korelasi yang lebih bagus.

Tabel 2. Rotated Component Matrix 1

\begin{tabular}{|l|l|l|l|l|l|}
\hline \multicolumn{5}{|l|}{ Component } & \multicolumn{4}{l|}{} \\
\hline & 1 & 2 & 3 & 4 & 5 \\
\hline i1 & & & & & 0,731 \\
\hline i2 & & & & & 0,843 \\
\hline i3 & & 0,665 & & & \\
\hline i4 & & 0,768 & & & \\
\hline i5 & & 0,740 & & & \\
\hline i6 & & 0,750 & & & \\
\hline i7 & 0,789 & & & & \\
\hline i8 & 0,734 & & & & \\
\hline i9 & 0,634 & & 0,609 & & \\
\hline i10 & & & 0,873 & & \\
\hline i11 & & & 0,867 & & \\
\hline i12 & & & & & \\
\hline i13 & 0,794 & & & & \\
\hline i14 & & & & 0,930 & \\
\hline i15 & & & & 0,902 & \\
\hline i16 & 0,707 & & & & \\
\hline
\end{tabular}

Sumber: Data Primer, diolah

Adapun hasil dari proses rotasi dengan menghilangkan I9 adalah seperti terangkum dalam Tabel 3. Dari proses reduksi tersebut menyisakan sepuluh indikator yang tidak mempunyai korelasi ganda. Kesepuluh indikator tersebut mengelompok dalam empat faktor, yaitu Faktor 1 (I7, I9, I13, dan I16); Faktor 2 (I14 dan I15); Faktor 3 (I1 dan I2); dan Faktor 4 (I3 dan I6).

Tabel 3. Rotated Component Matrix 2

\begin{tabular}{|l|l|l|l|l|}
\hline & \multicolumn{5}{|c|}{ Component } \\
\hline & 1 & 2 & 3 & 4 \\
\hline i1 & & & 0,864 & \\
\hline i2 & & & 0,884 & \\
\hline i3 & & & & 0,665 \\
\hline i6 & & & & 0,892 \\
\hline i7 & 0,822 & & & \\
\hline i9 & 0,798 & & & \\
\hline i13 & 0,834 & & & \\
\hline i14 & & 0,935 & & \\
\hline i15 & & 0,931 & & \\
\hline i16 & 0,756 & & & \\
\hline
\end{tabular}

Sumber: Data Primer, diolah

\section{Penamaan Faktor}

Sampai langkah ini proses reduksi indikator sudah berhenti. Proses selanjutnya adalah penamaan faktor. Tabel 4 menunjukkan rangkuman penamaan faktor beserta indikatornya. Terdapat empat faktor, yaitu Faktor Kelembagaan, Faktor Ketaatan pada Syariah Islam, Faktor Pelayanan, dan Faktor Kesesuaian Produk.

Tabel 4. Penamaan Faktor

\begin{tabular}{|c|c|c|c|}
\hline i7 & Kemudahan yang disebabkan institusi/kantor & \multirow{4}{*}{ Faktor 1} & \multirow{4}{*}{ Faktor Kelembagaan } \\
\hline i9 & Lokasi LKS yang dekat dengan rumah & & \\
\hline i13 & Kedekatan LKS dengan kelompok jamaah yang diikuti & & \\
\hline i16 & Kecewa dengan lembaga keuangan konvensional & & \\
\hline i14 & Keyakinan bahwa produk LKS halal & \multirow{2}{*}{ Faktor 2} & \multirow{2}{*}{ Faktor Ketaatan pada Syariah Islam } \\
\hline i15 & Bagian dari ketaatan/menegakkan syariat Islam & & \\
\hline i1 & Proses administrasi dan pencairan yang mudah & \multirow{2}{*}{ Faktor 3} & \multirow{2}{*}{ Faktor Pelayanan } \\
\hline i2 & Adanya program jemput bola & & \\
\hline i3 & Akad dan produk yang sesuai dengan kebutuhan & \multirow{2}{*}{ Faktor 4} & \multirow{2}{*}{ Faktor Kesesuaian Produk } \\
\hline i6 & Tingkat return yang ditawarkan bersaing & & \\
\hline
\end{tabular}

Sumber: Data Primer, diolah 


\section{Uji Reliabilitas}

Ide pokok yang terkandung dalam konsep reliabilitas adalah sejauhmana hasil suatu pengukuran dapat dipercaya. Secara empiris, tinggi rendahnya reliabilitas ditunjukkan oleh suatu angka yang disebut koefisien reliabilitas. Secara teoritis, besarnya koefisien reliabitas berkisar antara 0 sampai 1 , tetapi pada kenyataannya koefisien sebesar 1 dan 0 tidak pernah dijumpai. Koefisien reliabilitas yang semakin mendekati 1 berarti semakin dapat dipercaya.

Tabel 5. Uji Reliabilitas

\begin{tabular}{|c|c|}
\hline Faktor & Cronbach Alpha \\
\hline Faktor 1 & 0,803 \\
\hline Faktor 2 & 0,907 \\
\hline Faktor 3 & 0,708 \\
\hline Faktor 4 & 0,499 \\
\hline
\end{tabular}

Sumber: Data Primer, diolah

Uji reliabilitas dilakukan setelah hasil dari analisis faktor karena nilai Alpha lebih besar dari 0,4, berarti semua instrumen yang dipakai memenuhi syarat dan reliable.

\section{Analisis Komprehensif Temuan Faktor}

Faktor yang paling berperan dominan adalah faktor kelembagaan. Faktor kelembagaan yang diperhatikan nasabah dalam menggunakan lembaga keuangan syariah adalah fasilitas kemudahan sebagai hasil kerja sama lembaga keuangan syariah dengan kantor tempat bekerja nasabah, kedekatan lokasi lembaga keuangan syariah dengan tempat tinggal nasabah, kedekatan lokasi lembaga keuangan syariah dengan tempat pertemuan kelompok/jamaah nasabah, dan kekecewaan nasabah terhadap lembaga keuangan konvensional. Kedekatan lokasi dan kemudahan merupakan indikator yang paling penting dalam faktor kelembagaan.

Faktor kedua adalah ketaatan pada syariah Islam dengan indikator anggapan bahwa produk lembaga keuangan syariah adalah halal dan indikator bahwa menggunakannya adalah bagian dari ketaatan/menegakkan syariah Islam. Hal ini menunjukkan masih rendahnya pemahaman nasabah terhadap syariah Islam pada ranah perniagaan. Pada kenyataannya masih banyak produk lembaga keuangan syariah yang tidak ada bedanya dengan lembaga keuangan konvensional. Akan tetapi, masyarakat menganggap produk tersebut halal karena telah diberikan embel-embel akad yang menggunakan bahasa Arab.

Faktor ketiga adalah faktor pelayanan dengan indikator proses administrasi dan pencairan yang mudah serta indikator adanya program jemput bola. Masyarakat pada umumnya masih pragmatis sehingga kemudahan administrasi dan jemput bola merupakan hal yang menarik, baik untuk mengajukan pembiayaan maupun untuk menabung. Bahkan banyak responden yang asal terima uang saja tanpa mempedulikan lembaga keuangannya apakah berdasarkan syariah Islam atau tidak.

Faktor terakhir adalah faktor kesesuaian produk dengan indikator akad dan produk sesuai dengan kebutuhan dan indikator tingkat return yang ditawarkan bersaing. Pada kenyataannya, return yang dibayarkan banyak yang bersifat tetap besarnya (seperti suku bunga), hanya saja diberi istilah margin atau bahkan bagi hasil. Masyarakat tidak terlalu memahami esensi dari akadakad tersebut dan hanya melihat besarnya return dan kesesuaian produk dengan kebutuhannya saja.

\section{SIMPULAN}

Dari pemaparan sebelumnya dapat ditarik kesimpulan bahwa faktor-faktor yang mempengaruhi seseorang untuk menggunakan lembaga keuangan syariah adalah faktor kelembagaan, ketaatan terhadap syariah Islam, faktor pelayanan, dan faktor kesesuaian produk.

Temuan ini senada dan mendukung temuan-temuan penelitian serupa sebelumnya, seperti yang dipaparkan pada sub-bahasan sebelumnya. Penelitian ini mempunyai implikasi bahwa untuk meningkatkan penggunaan lembaga 
keuangan syariah oleh masyarakat sebaiknya memfokuskan peningkatan kualitas pada halhal di luar syariah Islam karena dari ketiga faktor hanya ada satu faktor yang berkaitan dengan ketaatan pada syariah Islam dan juga didukung oleh temuuan bahwa pada umumnya masyarakat tidak memahami dan mempedulikan syariah Islam (asalkan sudah ada label berbahasa Arab dianggap sudah mencukupi).

Penelitian ini mempunyai kelemahan dalam hal sampling karena menggunakan non probability (disebabkan peneliti tidak memungkinkan mengetahui populasi yang merupakan keseluruhan nasabah lembaga keuangan syariah), maka hasilnya bersifat studi kasus dan tidak dapat digeneralisir sebagai perilaku masyarakat Provinsi DIY. Diharapkan instansi yang merupakan regulator dari lembaga keuangan syariah yang ada melakukan penelitian serupa dengan metode sampling probabiliy.

\section{DAFTAR PUSTAKA}

Andri Soemitra, M.A., 2009, Bank dan Lembaga Keuangan Syariah, Jakarta: Kencana Prenada Media Group.

Anto, Hendri MB dan Setyowati, Desti, editor Nurul Huda dan M.E. Nasution, 2009, "Current Issues Lembaga Keuangan Syariah", cet. 1, Jakarta: Kencana Prenada Group.

Baldwin, et. al., 2002, "Theoritical Foundations of Islamic Economics", cet. 1， IRTI-IDBI， Jeddah-Arab Saudi.

Bank Indonesia Padang, dan Lembaga Penelitian Universitas Andalas, 2001, Potensi, Preferensi dan Perilaku Masyarakat terhadap Bank Syariah di Sumatera Barat, Penelitian, Bank Indonesia dalam www.bi.go.id.

Bank Indonesia dan LP-IPB, 2004, Potensi, Preferensi, dan Perilaku Masyarakat terhadap Bank Syariah di Wilayah Jawa Barat, Penelitian, Bank Indonesia dalam www.bi.go.id.
Bank Indonesia dan PPKP-LP Undip, 2000, Penelitian Potensi, Preferensi, dan Perilaku Masyarakat terhadap Bank Syariah di Wilayah Jawa Tengah dan Daerah Istimewa Yogyakarta, Penelitian, Bank Indonesia, dalam www.bi.go.id.

Bank Indonesia dan PPBEI-FE Unbraw, 2000, Penelitian Potensi, Preferensi dan Perilaku Masyarakat terhadap Bank Syariah; Studi Pada Wilayah Propinsi Jawa Timur, Penelitian, Bank Indonesia dalam www.bi.go.id.

Bank Indonesia Yogyakarta, 2010, Statistik Ekonomi dan Keuangan Daerah DIY Bulan Agustus, Yogyakarta: Bank Indonesia Yogyakarta

Direktorat Perbankan Syariah, Bank Indonesia, dan Institut Pertanian Bogor, 2004, Potensi Preferensi dan Perilaku Masyarakat terhadap Bank Syariah di Wilayah Kalimantan Selata, Penelitian, Institut Pertanian Bogor, dalam www.bi.go.id.

Cooper, DR., and Schindler, PS., 2001, "Business Research Methods 7th Ed", McGraw-Hill Irwin.

Donna,DR, 2006, Variabel-variabel yang Mempengaruhi Pembiayaan pada Perbankan Syariah di Indonesia, Tesis. Tidak Diterbitkan.

Eswaran, M. and A. Kotwal,1990, "Implications of Credit Constraints for Risk Behaviour in Less Developed Economies", Oxford Economic Papers, Vol. 42.

Hair, JF., dkk,, 2010, “Multivariate Data Analysis a Global Perspective $7^{\text {th }}$ edition", Pearson Global Edition.

Gujarati, DN. Dan Porter, DC., 2009, “Basic Econometrics $5^{\text {th }}$ edition", McGrawHill International Edition. 
Iqbal, Munawar, et. al., 1998, "Challenges Facing Islamic Banking", cet. 1, Jeddah-Arab Saudi: IRTI-IDB.

Karim, A, 2003, Bank Islam Analisis Fiqih dan Keuangan, Jakarta: The International Institute of Islamic Thought Indonesia.

Khan, SR, 1984, “An Economic Analysis of a PLS Model for the Financial Sector", The Pakistan Journal of Economics, $3(2)$.

Korteweg, P dan Van Loo, P, 1977, “The Market for Money and the Market for Credit", Leiden: Martinus Nijhoff Social Sciences Division.

Kuncoro, M, 2003, Metode Riset untuk Bisnis dan Ekonomi, Jakarta: Penerbit Erlangga.

Ligon, E, 1998, “Risk Sharing and Information in Village Economies", Review of Economic Studies, 65, 847-864.

Nasution, A.R., 2006, Analisis Potensi dan Preferensi Masyarakat terhadap Bank Syariah di Wilayah Kota Medan, Tidak Diterbitkan.
Santosa, S. dan Tjiptono, F., 2001, Riset Pemasaran: Konsep dan Aplikasi dengan SPSS. PT Elex Media Komputindo. Jakarta.

Sub Dinas Koperasi Provinsi DIY, 2010, Jumlah Koperasi di Provinsi DIY, Tidak Diterbitkan

Schaik, D, 2001, "Islamic Banking. The Arab Bank Review", 3(1): 45-52.

Shams, R., 2004, "A Critical Assessment of Islamic Economic", HWWA Discussion Thesis, 281: 1-12.

Sharma, S., 1996, “Applied Multivariate Analysis", John Wiley and Sons, Inc.

Seyed, dan Makiyan, N, 2001, "The Role of Rate of Return on Loans in the Islamic Banking System of Iran", International Journal of Islamic Financial Services, 3(3).

Wijaya, A, 2006, Segmentasi Pasar dan Perilaku Nasabah terhadap Lembaga Keuangan Syariah di Wilayah Yogyakarta dan Implikasi Strategi Pemasarannya, Tesis, Tidak Diterbitkan. 